\title{
Population Biology of Allocreadium lobatum Wallin, 1909 (Digenea: Allocreadiidae) in the Creek Chub, Semotilus atromaculatus, Mitchill (Osteichthyes: Cyprinadae), in a Nebraska Creek, USA
}

\author{
Monte S Willis \\ Harold W Manter Laboratory, University of Nebraska State Museum, Lincoln, NE 68588, USA
}

\begin{abstract}
Allocreadium lobatum Wallin, 1909 has been reported in cyprinid species of freshwater fish in Canada and in the United States. The population biology of A. lobatum in the host Semotilus atromaculatus Mitchill was studied from May through December 1991, in a USA creek. Overall prevalence (64\%) and mean intensity (4.4 \pm 0.4$)$ were greater than previously reported while abundance, reported for the first time, was $2.8 \pm 0.3$. Several trends in A. lobatum population biology as a function of S. atromaculatus length were identified. Mean intensity and abundance of A. lobatum increased with host size and significant differences in prevalence and $\mathrm{A}$. lobatum lengths were found to correlate with host lengths.
\end{abstract}

Key words: population biology - Digenea - Allocreadium lobatum - Cyprinidae - Semotilus atromaculatus

The digenetic trematode Allocreadium lobatum Wallin, 1909, an intestinal fluke found mainly in cyprinid species of freshwater fish, has been reported in the Canadian providences of British Columbia, Ontario, Quebec, Newfoundland, and New Brunswick (Doss 1963, Hoffman 1967, Margolis \& Arthur 1979, Rand \& Burt 1985). In the United States it has been reported in regions from Maine (Wallin 1909) to Idaho (Mayes 1976) and from Illinois to Michigan (DiGiusti 1962, Camp 1989) including Nebraska (Mayes 1976). In total, these studies report A. lobatum from at least 21 species of freshwater fishes in North America (Doss 1963, Hoffman 1967, Margolis \& Arthur 1979, Rand \& Burt 1985, Camp 1989).

The first intermediate host for A. lobatum is a sphaeriid clam (Pisidium spp.) (Schell 1985, Camp 1989), and the second an amphipod (Gammarus pseudolimnaeus Bousfield and Crangonyx gracilis S.I. Smith) (DeGiusti 1962, Schell 1985, Camp 1989). A. lobatum has been shown to reach sexual maturity in fish (Wallin 1909, Wootton 1957, Hoffman 1967, Schell 1985) or progenetically in their arthropod second intermediate host (DeGiusti 1962) or in the isopod Caecidotea communis Say (Muzzall 1981).

Corresponding address: Omaha VA Medical Center, Research Service 151, R321, 4101 Woolworth Ave., Omaha, NE 68105-1850, USA

Fax: +1-646-924-2480. E-mail: montewillis@juno.com Received 13 June 2000

Accepted 16 November 2000
Previously reported A. lobatum infections in Semotilus spp. (Rand \& Burt 1985, Camp 1989) have identified seasonal and host size trends in prevalence, mean intensity, and seasonal maturation from New Brunswick, Canada and Indiana, USA. The objectives of this study were to determine: (1) if these trends were similar to those found in a Nebraska, USA creek; (2) differences in the prevalence, mean intensity, and abundance as a function of Semotilus atromaculatus length; (3) the growth (length) of A. lobatum as a function of $S$. atromaculatus for the first time.

\section{MATERIALS AND METHODS}

From May to December 1991, 228 individual S. atromaculatus (creek chub) were collected from Elk Creek, a creek $60 \mathrm{~km}$ in length located in west Lancaster County, Nebraska. The average depth of Elk Creek is $0.2 \mathrm{~m}$, the average width $2.3 \mathrm{~m}$, and the substrate a silt, muck type (Maret $\&$ Peters 1980). All collections were taken from an area approximately $2.5 \mathrm{~km}$ in total length. Creek chubs were sampled from the same areas weekly from May until October and monthly in November and December when a solid ice cover and dwindling numbers of fish made weekly collections impractical. Fish were captured with a $1.5 \mathrm{~m}$ seine $(1 \mathrm{~cm}$ mesh size), transported live to the laboratory, and examined within $24 \mathrm{~h}$ of capture. The alimentary tract was removed from each fish, and examined in distilled water with the aid of a stereo microscope for metazoan parasites.

All recovered metazoan parasites were counted, fixed in boiling AFA (alcohol-formalin-acetic acid) and stored in $70 \%$ ethanol. Specimens were hy- 
drated in an alcohol series, stained with Mayer's hematoxylin, dehydrated, cleared in methyl benzoate, and mounted in Canada balsam.

To determine the seasonality of A. lobatum maturation, worms were categorized as immature, mature, or gravid based on the criteria of Bell and Smyth (1958) and later used by Rand and Burt (1985) and Camp (1989) as follows: immature (vitellaria undeveloped, testes and ovary distinct or indistinct, eggs absent); mature (granular vitellaria extending anteriorly at least to the posterior testis, eggs absent); and gravid [vitellaria thick and granular, $\operatorname{egg}(\mathrm{s})$ present]. The analyses were based on 636 helminth specimens of which 583 were used to determine reproductive development. The identification to specific level of A. lobatum was confirmed by comparison to mounted paratypes (USNM No. 81415) and syntypes (USNM No. 49986) from Wallin (1909) from the US National Museum Helminthological Collection. Voucher specimens from previous studies (Mayes 1976) were also used (Harold W Manter Laboratory nos. 19732, 19829, 20355-20364, 23667, 35006). Voucher specimens for the present study were deposited at the Harold W Manter Laboratory (HWML 35114 through 35140).

The terms prevalence, mean intensity, and abundance follow the recommendations of Bush et al. (1997). Differences in prevalence were analyzed using the Fisher's exact test while mean intensity, abundance, and comparison of A. lobatum length to $S$. atromaculatus length was analyzed using a non-parametric one-way ANOVA. A Newman-Keuls multiple comparison test was used to determine significance in mean intensity and abundance among individual groups. Tukey's
(HSD) multiple comparison test was used to determine significance in A. lobatum lengths found in $S$. atromaculatus lengths. Significant differences in parasite maturity were determined using a $\chi^{2}$ test. Monthly distribution of parasite lengths were analyzed using a Kruskall-Wallis test. In all analyses, $\mathrm{P}$ values less than 0.05 were considered significant. All statistical analyses were performed using Prophet 5.0 (BBN Systems and Technologies 1996), SigmaStat (Jandel Scientific 1994), or SAS 6.10 (SAS Institute Inc., Cary, NC).

\section{RESULTS}

Six hundred thirty-six A. lobatum were collected from the stomach and intestine of 228 creek chubs from May to December 1991. Samples of other fish species (11 Nortopis lutrensis Baird and Girard, red shiner; 8 Pimephales promelas Rafinesque, fathead minnow; 7 Lepomis cyanellus Rafinesque, green sunfish; 6 Ictalurus natalis Lesueur, yellow bullhead) present in Elk Creek did not host A. lobatum. Therefore, S. atromaculatus was the only host for A. lobatum and was the only parasite found in $S$. atromaculatus throughout the study. Based on five sample collections, $S$. atromaculatus was found to represent $>80 \%$ of all fish collected.

During the course of the entire study, 146 of the 228 chubs were infected (64\% prevalence), mean intensity was $4.4 \pm 0.4$, and abundance was $2.8 \pm$ 0.3 (Table I). Statistically significant changes in prevalence were observed between months $(\mathrm{P}=0.005)$, peaking in June, dipping in the months of August and September, and peaking again in November (Table I). Mean intensity and abundance did not change significantly $(\mathrm{P}>0.05)$ between months (Table I) and the mean length of hosts (9.2 $\pm 2.1 \mathrm{~cm})$ did not change between months $(\mathrm{P}>0.05)$.

TABLE I

Monthly prevalence, mean intensity, and abundance of Allocreadium lobatum in Semotilus atromaculatus from May to December 1991

\begin{tabular}{lccccrr}
\hline $\begin{array}{l}\text { Month } \\
(1991)\end{array}$ & $\begin{array}{c}\text { No. fish } \\
\text { examined }\end{array}$ & Prevalence & $\begin{array}{c}\text { No. worms } \\
\text { recovered } \\
\text { (range) }\end{array}$ & $\begin{array}{c}\text { Mean } \\
\text { intensity } \\
\pm \text { SE }\end{array}$ & $\begin{array}{c}\text { Abundance } \\
\pm \text { SE }\end{array}$ & $\begin{array}{c}\text { Body length } \\
\text { of host (cm) } \\
\text { Mean (range) }\end{array}$ \\
\hline May & 5 & $4(80.0)$ & $19(2-8)$ & $4.8 \pm 1.4$ & $3.8 \pm 1.4$ & $11.7(6.5-16.0)$ \\
June & 35 & $26(74.3)^{a}$ & $119(1-25)$ & $4.6 \pm 1.0$ & $3.4 \pm 0.8$ & $8.5(4.4-16.8)$ \\
July & 50 & $33(66.0)$ & $138(1-18)$ & $4.1 \pm 0.7$ & $2.7 \pm 0.5$ & $9.4(5.7-18.2)$ \\
August & 33 & $18(54.5)^{b}$ & $70(1-16)$ & $3.9 \pm 0.9$ & $2.1 \pm 0.6$ & $8.8(6.1-18.2)$ \\
September & 60 & $28(45.9)^{a, c}$ & $112(1-22)$ & $4.0 \pm 0.8$ & $1.9 \pm 0.5$ & $9.5(6.5-13.7)$ \\
October & 17 & $12(70.6)$ & $45(1-8)$ & $3.8 \pm 0.8$ & $2.7 \pm 0.7$ & $9.9(4.9-14.0)$ \\
November & 26 & $23(88.5)^{b, c}$ & $123(1-21)$ & $5.4 \pm 1.2$ & $4.7 \pm 1.1$ & $8.9(5.3-18.0)$ \\
December & 2 & $2(100)$ & $10(5)$ & $5.0 \pm 0.0$ & $5.0 \pm 0.0$ & $9.3(8.8-9.7)$ \\
\hline Total & 228 & $146(64.0)^{d}$ & $636(1-25)$ & $4.4 \pm 0.4^{e}$ & $2.8 \pm 0.3^{e}$ & $9.2(4.4-18.2)^{e}$
\end{tabular}

$a-c$ : statistically significant differences found between corresponding letters $(\mathrm{P}<0.05)$; d: statistically significant differences found between monthly prevalences $(\mathrm{P}<0.05)$; e: no statistically significant differences found between monthly measurements $(\mathrm{P}>0.05)$. 
To further describe monthly population dynamics of A. lobatum in S. atromaculatus, the occurrence of A. lobatum maturity levels were determined (Fig. 1). During the months of June, July, and August the population was composed largely of gravid individuals $(79,96$, and $78 \%$, respectively) while in September, October, and November the population consisted primarily of immature individuals $(90,91$, and $66 \%$, respectively). These differences in monthly parasite maturation were found to be significant $(\mathrm{P}=0.0001)$. All maturity stages of A. lobatum were collected throughout the study except mature (non-gravid Stage B) in May and October (Fig. 1).

Monthly distribution of $A$. lobatum length was significantly different between months $(\mathrm{P}=0.0001)$ (Fig. 2). Fig. 2 illustrates that in general, the $A$. lobatum lengths during the summer months of June, July, and August were longer than those in May (earlier) or in September-December (later). Worms less than $0.5 \mathrm{~mm}$ were absent in all months except November.

During the course of this study, $S$. atromaculatus in $1 \mathrm{~cm}$ interval size classes could be found ranging from $4-19 \mathrm{~cm}$. All groups were found to be infected with A. lobatum, except in the $17-18 \mathrm{~cm}$ size class (Table II). Seventy-five percent (171/228) of all S. atromaculatus captured and $74 \%$ of S. atromaculatus infected (108/146) were in the $5-11 \mathrm{~cm}$ range (Table II). Peak A. lobatum

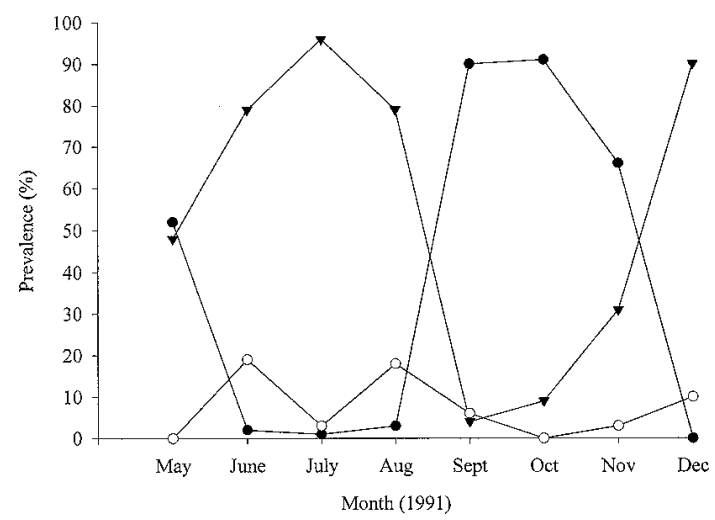

Fig.1: prevalence of immature, mature, and gravid Allocreadium lobatum recovered from Semotilus atromaculatus collected May to December 1991. Immature: Stage A (•); Mature: Stage B (O); Gravid: Stage C (, )

prevalence was found in the 5-6 $(90.5 \%, \mathrm{~N}=21)$ and $12-13(90 \%, \mathrm{~N}=9)$ groups of $S$. atromaculatus $(\mathrm{P}<0.01)$ (Table II). While monthly mean intensity and abundance of A. lobatum did not differ statistically in this study, it increased concomitantly with $S$. atromaculatus length as illustrated in Table II ( $\mathrm{P}=0.023$ and $\mathrm{P}=0.019$, respectively). A. lobatum in fish greater than $15 \mathrm{~cm}$ did not appear to follow this trend, but the total number of fish found in this range was low ( $6 \%$ of total), making statistical inferences about this data impossible $(\mathrm{P}>0.05)$.

\section{TABLE II}

Prevalence, mean intensity, and abundance of Allocreadium lobatum in different size classes of Semotilus atromaculatus

\begin{tabular}{|c|c|c|c|c|c|c|}
\hline $\begin{array}{l}\text { Size } \\
\text { Class } \\
(\mathrm{cm}) \\
\end{array}$ & $\begin{array}{l}\text { No. } \\
\text { fish } \\
\text { total }\end{array}$ & $\begin{array}{c}\text { No. fish } \\
\text { infected } \\
\text { (prevalence) }\end{array}$ & $\begin{array}{l}\text { Mean length } \\
\text { infected fish } \\
\quad( \pm \mathrm{SE})\end{array}$ & $\begin{array}{l}\text { No. of } \\
\text { worms } \\
\text { (range) }\end{array}$ & $\begin{array}{c}\text { Mean } \\
\text { intensity } \\
( \pm \mathrm{SE})\end{array}$ & $\begin{array}{c}\text { Mean } \\
\text { abundance } \\
( \pm \mathrm{SE})\end{array}$ \\
\hline $4-4.99$ & 9 & $5(55.6)^{a, b}$ & $4.6(0.14)$ & $11(1-5)$ & $2.2(0.7)$ & $1.22(0.6)$ \\
\hline $5-5.99$ & 21 & $19(90.5)^{a, c, d, e}$ & $5.6(0.06)$ & $51(1-8)$ & $2.7(0.5)$ & $2.43(0.5)$ \\
\hline $6-6.99$ & 29 & $15(51.7)$ & $6.54(0.07)$ & $45(1-6)$ & $3.0(0.4)$ & $1.55(0.4)$ \\
\hline $7-7.99$ & 30 & $15(50.0)^{b, h}$ & $7.40(0.07)$ & $64(1-18)$ & $4.3(1.2)$ & $2.13(0.7)$ \\
\hline $8-8.99$ & 29 & $18(62.1)^{d}$ & $8.42(0.08)$ & $61(1-15)$ & $3.4(0.8)$ & $2.10(0.6)$ \\
\hline $9-9.99$ & 32 & $22(68.8)^{g}$ & $9.47(0.07)$ & $119(1-22)$ & $5.4(1.1)$ & $3.69(0.9)$ \\
\hline $10-10.99$ & 30 & $19(63.3)^{\mathrm{c}}$ & $10.42(0.06)$ & $77(1-12)$ & $4.1(0.7)$ & $2.57(0.6)$ \\
\hline $11-11.99$ & 11 & $8(72.7)$ & $11.34(0.08)$ & $65(1-21)$ & $8.1(2.2)$ & $5.91(2.0)$ \\
\hline $12-12.99$ & 10 & $9(90.0)^{f, h}$ & $12.37(0.11)$ & $55(1-20)$ & $6.1(2.0)$ & $5.50(1.9)$ \\
\hline $13-13.99$ & 8 & $6(75.0)$ & $13.43(0.13)$ & $28(1-12)$ & $4.7(1.8)$ & $3.50(1.5)$ \\
\hline 14-14.99 & 6 & $4(66.7)$ & $14.1(0.06)$ & $40(3-25)$ & $10(5.1)$ & 6.67 (3.9) \\
\hline $15-15.99$ & 2 & $1(50.0)$ & $15.3(0.00)$ & 4 (NA) & $4(0)$ & $2.00(2.0)$ \\
\hline $16-16.99$ & 3 & $2(66.7)$ & $16.4(0.40)$ & $11(3-8)$ & $5.5(2.5)$ & $3.67(2.3)$ \\
\hline $17-17.99$ & 3 & $0(00.0)^{e, f, g}$ & ND & ND & ND & ND \\
\hline $18-18.99$ & 5 & $3(60.0)$ & $18.13(0.09)$ & $5(1-3)$ & $1.7(0.9)$ & $1.0(0.6)$ \\
\hline Total & 228 & $146(64.0)^{i}$ & $9.2(0.3)$ & $636(1-25)$ & $4.4(0.4)^{i}$ & $2.79(0.3)^{i}$ \\
\hline
\end{tabular}

$a-h$ : statistically significant differences in prevalence found between corresponding letters between $S$. atromaculatus size classes $(\mathrm{P}<0.05)$; $i$ : statistically significant differences between $S$. atromaculatus size classes $(\mathrm{P}<0.05)$; ND: not determined as no samples were collected. 

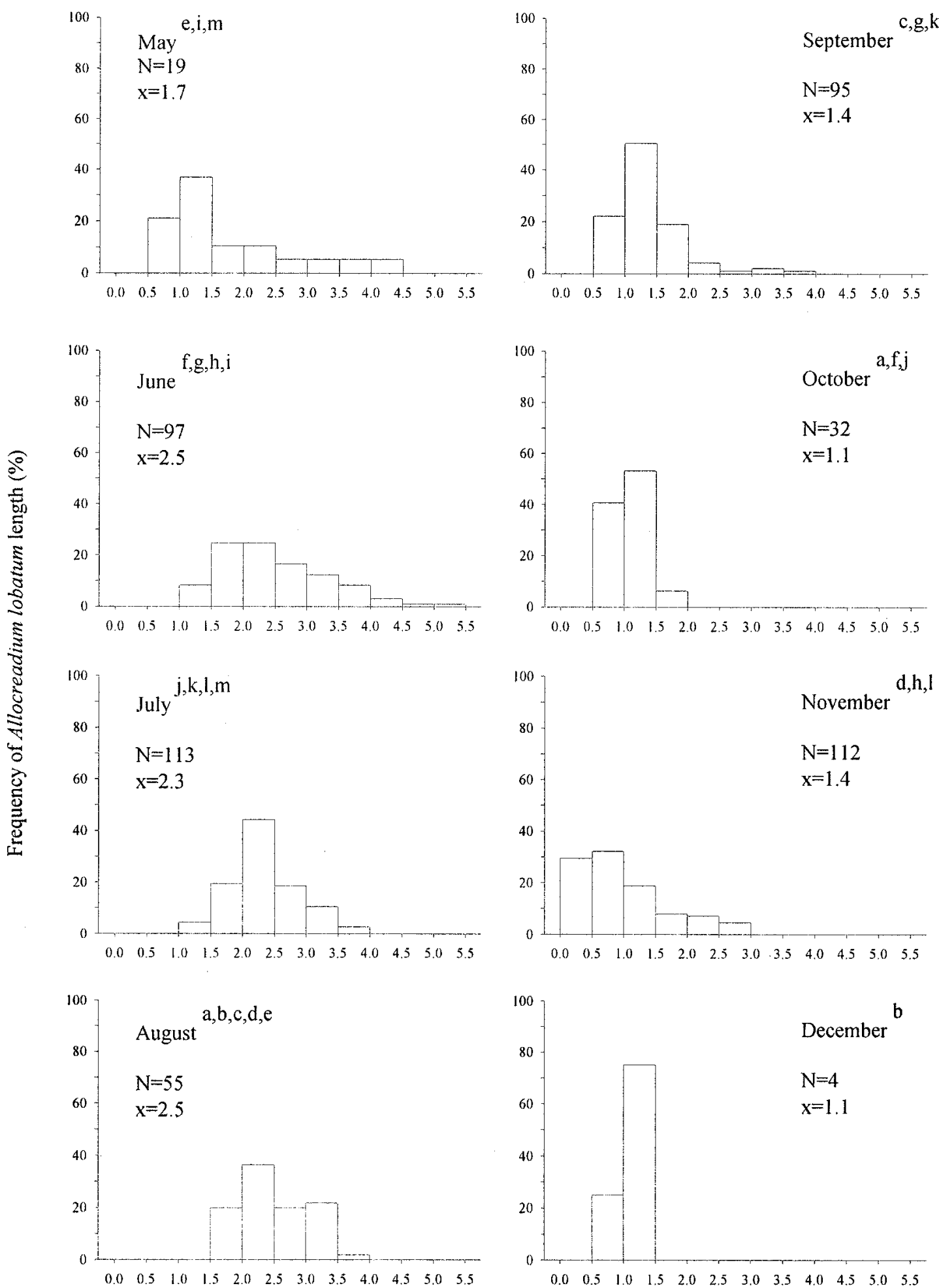

\section{Worm length $(\mathrm{mm})$}

Fig. 2: seasonal variation of Allocreadium lobatum length in Semotilus atromaculatus collected May to December 1991 (N: sample size, $\mathrm{x}$ : mean worm length). a-m: statistically significant differences found between corresponding letters $(\mathrm{P}<0.05)$. 
Comparison of mean A. lobatum length (mm) as a function of $S$. atromaculatus length is illustrated in Fig. 3. Average A. lobatum length ( \pm SE) throughout the course of this study was 1.91 $( \pm 0.04) \mathrm{mm}$. Overall, A. lobatum length was significantly different depending on the size class of the host fish $(\mathrm{P}=0.0001)$, peaking in the $7-8 \mathrm{~cm}$ and 11-12 size class (Fig. 3).

Pisidium spp., the first intermediate host of $A$. lobatum, were found in silt near creek banks during the entire study. Approximately 175 were brought into the laboratory and kept for 14-28 days. They did not, however, shed cercaria in the laboratory.

\section{DISCUSSION}

Previous studies of the population biology of A. lobatum in the hosts Semotilus corporalis Mitchill and S. atromaculatus in New Brunswick, Canada (Rand \& Burt 1985) and Indiana, USA (Camp 1989), respectively, have described seasonal changes in prevalence and mean intensity peaking during the winter and spring which dramatically declined during the summer months. These studies also describe seasonal changes in parasite maturity. Differences in mean intensity as a function of host size (S. atromaculatus) have also been described, increasing with host size (Camp 1989). The current study reports seasonal changes in prevalence but not mean intensity of $A$. lobatum in $S$. atromaculatus as well as seasonal changes in maturation that differ from previous studies. Additionally, the effects of host size on $A$. lobatum length is reported for the first time. These findings demonstrate diversity in the population biology of A. lobatum.

Overall prevalence of A. lobatum was greater in this study $(64 \%)$ than has previously been reported by Rand and Burt $(1985,49 \%$ in $S$. corporalis) or Camp $(1989,31.3 \%$ in $S$. atromaculatus). Monthly prevalence cycled so that September had the lowest prevalence of $45.9 \%$ (Table I) differing from previous studies which describe the lowest prevalence of $0 \%$ during the summer months June through September (19841987) (Camp 1989), or 0-20\% during these same months (1978-1980) (Rand \& Burt 1985). The prevalence of A. lobatum as a function of host length has previously been unreported and was determined to be highest in the 5-6 and $12-13 \mathrm{~cm}$ size host (Table II). This may reflect coincident availability of infected second intermediate hosts and fish which will be discussed next.

S. atromaculatus is a common freshwater inhabitant in streams throughout North America generally east of the Rocky Mountains (Eddy \& Underhill 1978). It is a schooling species inhabiting small to medium streams, generally streams of less than $12 \mathrm{~m}$ width and gravel-sand-silt substrate, rivers, and occasionally lakes (Scott \& Crossman 1973, Trautman 1981, Sublette et al. 1990). Food consumption of $S$. atromaculatus demonstrates little selectivity as it has been reported that food consumption varies from molluscs, plants, and insects to amphibians and is dependent on the size of the host

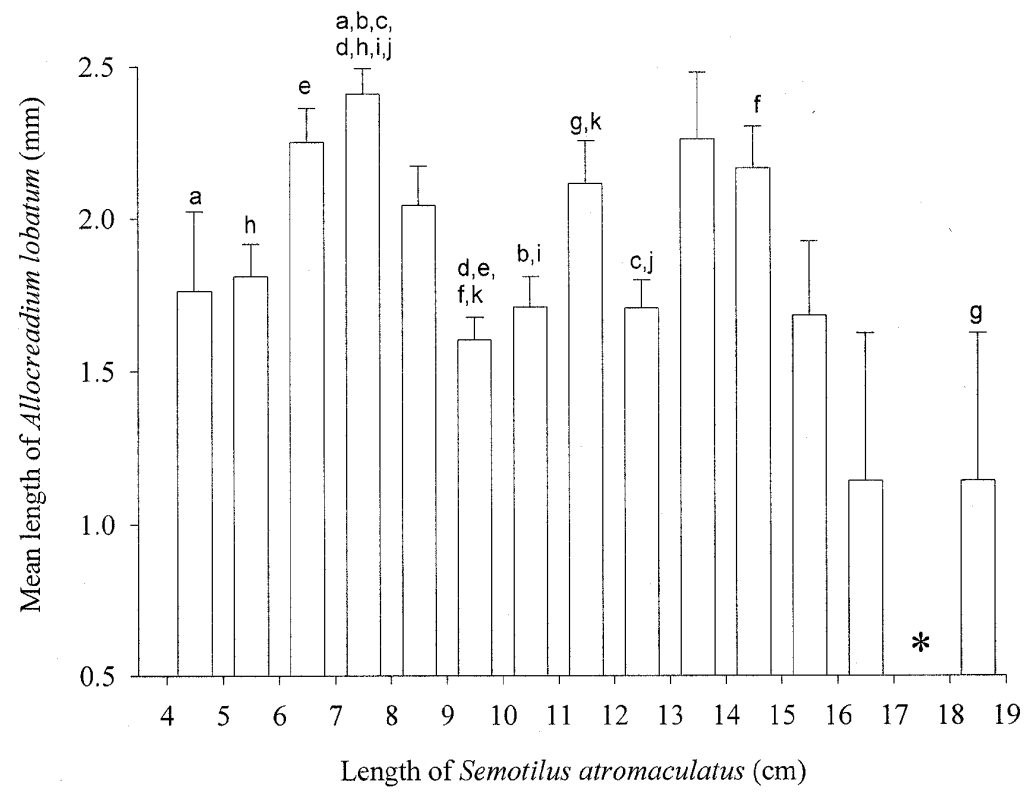

Fig. 3: mean length of Allocreadium lobatum recovered from Semotilus atromaculatus as a function of host length collected May-December 1991. a-k: statistically significant differences found between corresponding letters $(\mathrm{P}<0.05)$; *: no $S$. atromaculatus collected in this size range. 
(Dinsmore 1962, Miller 1964, Barber 1971, Moshenko 1973, Copes 1975, Propst 1982). Taken together, these studies demonstrate that (1) minnows $2-4 \mathrm{~cm}$ in length mainly consume chironomids larvae, as well as ceratopogonids, simuliids, and cecidomyids and ephemeropteran naiads; (2) minnows $4.1-6 \mathrm{~cm}$ in length consume larger prey such as tipulid larvae and dragonfly nymphs; (3) as minnows reach maturity at $4.1-6 \mathrm{~cm}$ in length mollusks and fish make up the bulk of the diet; and (4) minnows over $8.1 \mathrm{~cm}$ are primarily piscivourous. It is this size dependent food selectively and broadness of diet that may account for the increased prevalence of parasites in the two fish sizes. Interestingly, it is the mature fish $(>4 \mathrm{~cm})$ that have been shown to ingest preferentially molluses which are the second intermediate host of A. lobabum which may have been infected at the times the $12-13 \mathrm{~cm}$ fish were $4-6.1 \mathrm{~cm}$ and infected recently when the 5-6 $\mathrm{cm}$ were consuming them.

Two measures of parasite burden on a host species were taken in this study, mean intensity and abundance. In this study, overall mean intensity $(4.4 \pm 0.4)$ was similar to that reported by Rand and Burt (1985) in S. corporalis $(6.0 \pm 4.8)$ and greater than that described in S. atromaculatus by Camp (1989) $(2.8 \pm 0.2)$. While significant changes in monthly A. lobatum prevalence were observed in this study, differences in monthly mean intensity and abundance were not (Table I). In contrast, Camp (1989) found A. lobatum in S. atromaculatus mean intensity that changes seasonally peaking during the winter and spring and declining in the summer. Camp (1989) has demonstrated that A. lobatum are shed as water temperature increases, indicating that water temperatures in this study may not have increased as much as previous investigations because differences in mean intensity were not found. The mean intensity of A. lobatum increased as a function of $S$. atromaculatus length $(4-15 \mathrm{~cm})$ as shown in Table II as Camp (1989) previously reported. Due to the small size of the sample, fishes $>15 \mathrm{~cm}$ were not analyzed. The greater consumption of intermediate hosts by larger fish may explain heavier infections. The abundance of A. lobatum in $S$. atromaculatus was found to be $2.8 \pm 0.3$ is reported for the first time and did not differ significantly between months (Table I). Like mean intensity, abundance did increase as a function of fish length and appears to be dependent more on fish size than on seasonal trends (Table II). It appears there was a constant percentage of uninfected fish, as changes in mean intensity followed changes in abundance quite closely. A consistent monthly distribution of host length (as shown by mean host length in Table I) may be responsible for the lack of monthly changes in mean intensity or abundance.
It has been demonstrated that seasonal changes in the water environment (such as temperature, conductivity, and $\mathrm{pH}$ ) can affect the occurrence of aquatic host parasites (Dogiel et al. 1970). The seasonal changes in prevalence and lack of monthly changes in mean intensity of A. lobatum may be explained by this. The fact that changes were found that differed from previous studies may have to do with factors such as $\mathrm{pH}$ and conductivity that were not measured in this study. Additionally, temperature may have effects on the rate of development, life expectancy, and infection rate of the parasite (Bauer 1959, Kennedy 1975, Chubb 1977, Evans 1977, Möller 1978).

Annual life cycles are well known in Allocreadium spp. in general (Chubb 1977, Rand \& Burt 1985, Camp 1989, Camp 1992, Moravec 1992) and A. lobatum in Semotilus species (DeGiusti 1962, Rand \& Burt 1985, Camp 1989). Camp (1989) has reported that Stage A (immature) A. lobatum in S. atromaculatus are found mainly in autumn (September-November, 37.6\%), and winter (December-February, 21\%) but rarely in the spring (March-May, 6.2\%), and not in the summer (June-August, 0\%). Stage B (mature, not gravid) A. lobatum are found mainly in autumn and winter months (September-February, 27.1\%, 38.5\%), fewer in the Spring (March-May, 6\%), and not in the summer (June-August, 0\%). Stage C (gravid) A. lobatum are found through the year, being lowest in autumn and winter (September-February, $35.3 \%-40.5 \%$ ), and highest in spring and summer (March-August, 87.8\%-100\%). Overall, the autumn and winter months had approximately $1 / 3$ of each stage present, whereas spring and summer were mainly Stage $C$ gravid A. lobatum.

Rand and Burt (1985) have reported seasonal changes in maturation in which the population was composed mainly of immature and mature (Stages $\mathrm{A}$ and $\mathrm{B}$ ) parasites during autumn months (AugustNovember 1979 and 1980) with gravid individuals not exceeding $42 \%$. The percentage of gravid individuals in the population increased to at least $60 \%$ by February, reaching highest levels from May to July (75-100\%) which subsequently decreased to low summer levels. Gravid (Stage C) parasites were not found during autumn months, immature and mature individuals were recovered in all of the collections (Rand \& Burt 1985).

The present study found predominantly Stage C (gravid) parasites in June, July, and August whereas Stage A (immature) parasites were mainly collected in September, October, and November (Fig. 1). The time in which gravid parasites were present in the Rand and Burt (1985) study were from February until July, a much longer period than found in this study. There was a small percentage 
(0-20\%) of Stage B worms (mature, not gravid) found throughout the study reflecting that mature A. lobatum were most likely to be gravid if they were present. This contrasts to Camp (1989) who reported the considerable presence of Stage B parasites during autumn and winter months $(27.1 \%$ and $38.5 \%$ ). When Stage A (immature) parasites were present, they were the majority of parasites (September-November), whereas Camp (1989) showed an immature population that was never greater than $1 / 3$ of the population in September-November (37.6\%). This peak of Stage A (immature) parasites found in this study, however, correlates with the peak prevalence of immature parasites Camp (1989) found in September-November.

The finding of few mature worms after gravid parasites were gone in September through December suggest that these parasites died shortly after oviposition (Fig. 1), a finding which other investigators have reported for $A$. lobatum in $S$. atromaculatus (Rand \& Burt 1985). Further evidence of this mortality is the decrease in prevalence found during this transition period of mostly gravid adults to mainly immature parasites (Fig. 1) that were shorter in length (Fig. 2). The presence of immature A. lobatum throughout the study suggests a cyclic recruitment during the year, which lasts as long as second intermediate hosts are able to support infective metacercariae. Newly recruited A. lobatum that are seen in September then quickly mature in approximately one month. Many species of parasites found in the northern hemisphere have well defined seasonal cycles with spring maturation followed by death after reproduction in the summer (Kennedy 1977).

Complementary to these maturational findings, the length of A. lobatum increases May through August (Fig. 2). Longer parasites are found in the months of June, July, and August (Fig. 2) during which time most parasites were gravid (Fig. 1) indicating the height of their maturity. Previous studies have found that mean length of A. lobatum in S. corporalis (Rand \& Burt 1985) followed similar seasonal changes. Mean lengths were shown to increase from their lowest levels in August to their highest levels by June and July (Rand \& Burt 1985). During the months of September, October, and November a distribution of smaller parasites is seen (Fig. 2) which are mainly immature (Fig. 1) and do not increase in size. During these cold months it appears that the parasites are not increasing in size and the "appearance" of a gravid population in December (Fig. 1) is probably a reflection of the low sample number (only 5) collected during this month.

A. lobatum length as a function of $S$. atromaculatus length is described for the first time in this study (Fig. 3) to determine if there was a relationship between host and parasite length. Although density appeared to increase as a function of host length, such a clear correlation was not identified in mean length of $A$. lobatum as a function of host length (Fig. 3). Peak A. lobatum lengths were found primarily in the 7-8 cm and to a lesser extent the $11-12 \mathrm{~cm}$ group. Reasons for this finding are not clear and may indicate some other interactions of parasite and host unrelated to density.

Pisidium spp. were found during the entire study, but their role as first intermediate host was not proven experimentally because cercaria were not shed in the laboratory after collection. In a previous study (Camp 1989) more than 1,600 samples were needed to find seven infected with metacercaria $(0.4 \%)$, making it probable that not enough clams were collected in this study to find metacercariae.

Overall prevalence and mean intensity of $A$. lobatum in $S$. atromaculatus was greater in this study (64\% and $4.4 \pm 0.4$, respectively) than previously reported by other investigators (Rand \& Burt 1985, Camp 1989). Abundance, previously unreported, followed the same trends as mean intensity in this study and was $2.8 \pm 0.3$ overall. During the months of May through December, 1991, prevalence cycled such that September had the lowest (45.9\%) compared to previous descriptions of $0 \%$ or $0-20 \%$ (Rand \& Burt 1985, Camp 1989) during these same months. Seasonal changes in mean intensity were not found as previously described (Camp 1989), while seasonal changes in maturation stages and parasite sizes of A. lobatum in S. atromaculatus demonstrated mainly larger gravid parasites in the summer months and immature parasites in autumn similar to previous studies (Camp 1989). Prevalence of A. lobatum as a function of host length, previously unreported, was found to be highest in the 5-6 and 12-13 cm size host. The mean intensity of A. lobatum in this study increased as host size increased. As the density of parasite burden appeared to increase as a function of host length, the length of $A$. lobatum length appeared to be increased in two fish size groups $(7-8 \mathrm{~cm}$ and 11 $12 \mathrm{~cm}$ ) groups for reasons not altogether clear. Annual cycles in A. lobatum maturity and prevalence identified during the course of this study suggest an annual recruitment in which most gravid A. lobatum were lost in August and immature parasites were recruited in September. The population biology of $A$. lobatum in $S$. atromaculatus appears to be a dynamic process that is not consistent between populations as this study points out distinct differences from previous studies. 


\section{ACKNOWLEDGMENTS}

To Professor Mary H Pritchard for assistance with editing this manuscript and her continuing support and significant guidance that began with this study. To Skip Sterner, Collections Manager of the Harold W Manter laboratory, for assistance in collecting and academic support; Craig Smith, Matt Gross, and Chris Strange for their assistance in seining throughout the study; and Jeff Kollath from the Department of Preventive and Societal Medicine at the University of Nebraska Medical Center for assistance with statistical analyses used in this manuscript.

\section{REFERENCES}

Barber WE, Minckley WL 1971. Summer foods of the cyprinid fish Semotilus atromaculatus. Trans Amer Fish Soc 100: 283-289.

Bauer ON 1959. The ecology of parasites of freshwater fish: relationship between parasite and environment. In Parasites of Freshwater Fish and the Biological Basis for their Control, Bull State Sci Res Inst Lake River Fish, Leningrad, Vol XLIX, p. 3-215.

Bell EJ, Smyth JD 1958. Cytological and histochemical criteria for evaluating development of trematodes and pseudophyllidean cestodes in vivo and in vitro. Parasitology 48: 131-148.

Bush AO, Lafferty KD, Lotz JM, Shostak AW 1997. Parasitology meets ecology on its own terms: Margolis et al. revisited. J Parasitol 83: 575-583.

Camp Jr JW 1989. Population biology of Allocreadium lobatum (Trematoda: Allocreadiidae) in Semotilus atromaculatus. Am Midl Nat 122: 236-241.

Camp Jr JW 1992. Occurrence of Allocreadium in aquatic hosts from northern Indiana. Am Midl Nat 128: 203-208.

Chubb JC 1977. Seasonal occurrence of helminths in freshwater fishes. Part. I. Monogenea. In WHR Lumsden, R Muller, JR Baker (eds), Advances in Parasitology, Academic Press, London and New York, p. 133-199.

Chubb JC 1979. Seasonal occurrence of helminths in freshwater fishes. Part II. Trematoda. In WHR Lumsden, R Muller, JR Baker (eds), Advances in Parasitology, Academic Press, London and New York, p. 141-313.

Copes FA 1975. Ecology of the Creek Chub. Reports on Fauna and Flora of Wisconsin No. 12, 21 pp.

DeGiusti DL 1962. Ecological and life history notes on the trematode Allocreadium lobatum (Wallin, 1909) and its occurrence as a progenetic form in amphipods. J Parasitol 48: 22.

Dinsmore JJ 1962. Life history of the creek chub with emphasis on growth. Iowa Acad Sci 69: 296-301.

Dogiel VA, Petruschevshi GK, Polyanski YI 1970. Parasitology of Fishes, 3rd ed., Oliver and Boyd Ltd., Edinburgh (English translation by Z Kabata), 384 pp.

Doss MA 1963. Index-Catalogue of Medical and Veterinary Zoology. Trematoda and Trematode Diseases; Part 1: Supergenera and Genera $A$ and B, United States Government Printing Office, Washington, $157 \mathrm{pp}$.

Eddy S, Underhill JC 1978. How to Know the Freshwater Fishes, WC Brown Co., Dubuque, Iowa, 215 pp.
Evans NA 1977. The occurrence of Sphaerostoma bramae (Digenea: Allocreadiidae) in the roach from Worcester-Birmingham canal. J Helminthol 51: 189-196.

Hoffman GL 1967. Parasites of North American Freshwater Fishes, University of California Press, Berkeley and Los Angeles, 486 pp.

Kennedy CR 1975. Ecological Animal Parasitology, Blackwell Scientific Publications, Oxford, England, 163 pp.

Kennedy CR 1977. The regulation of fish parasite populations. In GW Esch, Regulations of Parasite Populations, Academic Press, New York, p. 63-109.

Maret TR, Peters EJ 1980. The fishes of salt creek basin, Nebraska. Trans Neb Acad Sci 8: 35-54.

Margolis L, Arthur JR 1979. Synopsis of the parasites of fishes of Canada. Bulletin of the Fisheries Research Board of Canada No. 199.

Mayes M 1976. The Adult Platyhelminth Parasites of Nebraska Fishes, Thesis, University of NebraskaLincoln, 207 pp. Available from University of Nebraska, Lincoln, NE: LD3656.5 1976 .M394x.

Miller RJ 1964. Behavior and ecology of some North American cyprinid fishes. Amer Midland Nat 72: 313-357.

Möller H 1978. The effects of salinity and temperature on the development and the survival of fish parasites. J Fish Biol 12: 311-324.

Moravec F 1992. Observations on the bionomy of Allocreadium isoporum (Looss, 1894) (Trematoda: Allocreadiidae). Folia Parasitol 39: 133-144.

Moshenko RW, Gee JH 1973. Diet, time and place of spawning, and environments occupied by creek chub (Semotilus atromaculatus) in the Mink River, Manitoba. J Fish Res Board Can 30: 357-362.

Muzzall PM 1981. Parasites of the isopod, Caecidotea communis, and amphipod Hyallela azteca, in New Hampshire. Proc Helminthol Soc Wash 48: 293-298.

Propst DL 1982. Warmwater Fishes of the Platte River Basin, Colorado; Distribution, Ecology, and Community Dynamics, Thesis, Colorado State University, Fort Collins, 283 pp.

Rand TG, Burt MDB 1985. Seasonal occurrence, recruitment, and maturation of Allocreadium lobatum Wallin, 1909 (Digenea: Allocreadiidae) in the fallfish, Semotilus corporalis Mitchell, in a New Brunswick, Canada, lake system. Can J Zool 63: 612-616.

Schell SC 1985. Trematodes of North America, University of Idaho Press, Moscow, 263 pp.

Scott WB, Crossman EJ 1973. Freshwater fishes of Canada. Fish Res Board Can Bull 184: 1-966.

Sublette JE, Hatch MD, Sublette M 1990. The Fishes of New Mexico, University of New Mexico Press, Albuquerque, $393 \mathrm{pp}$.

Trautman WB 1981. The Fishes of Ohio, Ohio State University Press, Columbus, 782 pp.

Wallin IE 1909. A new species of the trematode genus Allocreadium, with a revision of the genus and a key to the subfamily Allocreadinnae. Trans Am Microsc Soc 29: 50-66.

Wootton DM 1957. Studies on the life-history of Allocreadium alloneotenicum sp. nov. (Allocreadiidae-Trematoda). Biol Bull 113: 302-315. 